\title{
The Analysis of Interrelation between Kinetics of Propagation of Plastic Deformation and Initiation of Ductile Fracture
}

\author{
D. V. Laukhin, O. V. Beketov, N. O. Rott, I. A. Tyuterev, \\ S. V. Ivantsov, and V. D. Laukhin \\ Prydniprovs'ka State Academy of Civil Engineering and Architecture, \\ 24-a Chernyshevs'ky Str., \\ 49600 Dnipro, Ukraine
}

The work analyses a nature of interrelation between kinetics of propagation of plastic deformation and initiation of ductile fracture for low-carbon microalloyed steel $06 \mathrm{Kh} 1$. To reach the purpose of the work, the experiment is carried out. It includes stretching of a series of samples with deformation deceleration after reaching a certain level of loading. The study of the corresponding samples shows that the stage of crack origination is made through blocking the propagation of spreading the plastic deformation by the separation surfaces of the general and special types. At the same time, it is determined that the second stage (growth of microcracks) develops due to the simultaneous action of two mechanisms: accumulation of dislocations (the Cottrell model) and aggregation of several microcracks into single one.

Key words: hypopearlitic structure, ductile fracture, kinetics of crack propagation, blocking of dislocations, mechanisms of crack origination, mechanism of crack growth.

У роботі проаналізовано характер взаємозв'язку між кінетикою поширення пластичної деформації та зародженням в'язкого руйнування для низьковуглецевої мікролегованої сталі 06X1. Для досягнення поставленої в роботі мети було здійснено експеримент, який включав розтягання серії зразків з гальмуванням деформації по досягненні певного рівня навантаження. Дослідження відповідних зразків показали, що на стадії заро-

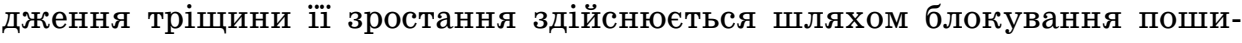

Corresponding author: D. V. Laukhin

E-mail:d.v.laukhin@gmail.com

Please cite this article as: D. V. Laukhin, O. V. Beketov, N. O. Rott, I. A. Tyuterev, S. V. Ivantsov, and V. D. Laukhin, The Analysis of Interrelation between Kinetics of Propagation of Plastic Deformation and Initiation of Ductile Fracture, Metallofiz. Noveishie Tekhnol., 39, No. 10: 1335-1343 (2017), DOI: 10.15407/mfint.39.10.1335. 
рення пластичної деформації поверхнями поділу як загального, так і спеціяльного типу. Разом з цим встановлено, що друга стадія (зростання мікротріщин) відбувається за рахунок одночасної дії двох механізмів: дислокаційного накопичення (модель Коттрелла) й об’єднання кількох мікротріщин в одну.

Ключові слова: феритоперлітна структура, в'язке руйнування, кінетика поширення тріщини, блокування дислокацій, механізми зародження тріщини, механізм зростання тріщини.

В работе проанализирован характер взаимосвязи между кинетикой распространения пластической деформации и зарождением вязкого разрушения для низкоуглеродистой микролегированной стали 06X1. Для достижения поставленной в работе цели был осуществлён эксперимент, который включал растяжение серии образцов с торможением деформации при достижении определённого уровня нагрузки. Исследование соответствующих образцов показали, что на стадии зарождения трещины её рост осуществляется путём блокирования распространения пластической деформации поверхностями раздела как общего, так и специального типа. Вместе с этим установлено, что вторая стадия (рост микротрещин) происходит за счёт одновременного действия двух механизмов: дислокационного накопления (модель Коттрелла) и объединения нескольких микротрещин в одну.

Ключевые слова: ферритоперлитная структура, вязкое разрушение, кинетика распространения трещины, блокировка дислокаций, механизмы зарождения трещины, механизм роста трещины.

(Received August 18, 2017)

\section{INTRODUCTION}

While studying the issue of plastic deformation under the influence of external loading, the following conclusion can be made: this process happens unevenly, which results in the creation of periodically heterogeneous reinforced surroundings (e.g. works [1, 2]).

In addition to that, while analysing the regularities of deformative grinding of metal structure and alloys, the authors of the works $[3,4]$ proved that plastic deformation spreads from grain to grain at the expense of tension occurrence (under the influence of external loading), which are conditioned by the interaction between the accumulation of dislocations and the barriers for their movement.

Theoretical study of the results of the mentioned works made it possible to conclude that while blocking the accumulation of dislocations by the barriers, activating of the sources of dislocations takes place, i.e. next to the barriers the density of crystal constitution defects increases [2]. Thus, the increase in the density of dislocation may lead to the appearance of atomic areas offset in one active area of slip [5]. Because 
of this, the main condition of crack appearance is the work of plastic deformation, which leads to the critical accumulation of defects, and as a result, to the creation of fracture origination [6]. Hence, the aim of this work is to analyse the probable places of origination of ductile fracture by means of the studying the work of plastic deformation.

\section{METHODOLOGY OF EXPERIMENTAL INVESTIGATIONS}

As a material for the investigation, $06 \mathrm{Kh} 1$ steel was chosen. Chemical composition and mechanical properties of this steel are given in Tables 1 and 2 , respectively.

To carry out the investigation, the samples of $06 \mathrm{Kh} 1$ steel were made. The samples were of cylindrical shape (according to the State Standard 1497-84) and one burnished and polished surface suitable for structural studies. Schematic image of the studied samples is given in Fig. 1. The preparation for structural studies was done according to the methodology offered in the work [7].

The samples underwent the extension without reaching the stage of fracture. The extension of the samples stopped at loading given in Table 3 and in Fig. 2. After loading stopped, the samples structure was studied (at places schematically depicted in Fig. 1) with the use of scanning electron microscope according to the methods offered in the work [8].

Figure 3 represents the structure of steel $06 \mathrm{Kh} 1$ before the beginning of deformation. The analysis of the data shows that the steel structure is ferrite-pearlite conglomerate. Herewith, as interphase and inner-phase surfaces of separation, there are both boundaries of general type (indicated with the arrow in Fig. 3, $a$ ) and boundaries of special type (indicated with the arrow in Fig. $3, b$ ). The identification of

TABLE 1. The chemical composition of 06Kh1 steel.

\begin{tabular}{c|c|c|c|c|c|c|c|c|c|c|c|c}
\hline \multirow{2}{*}{$\begin{array}{c}\text { No. } \\
\text { melting }\end{array}$} & \multicolumn{10}{c}{ Content of chemical elements, \% mass } \\
\cline { 2 - 10 } & $\mathrm{C}$ & $\mathrm{Cr}$ & $\mathrm{Cu}$ & $\mathrm{Mn}$ & $\mathrm{P}$ & $\mathrm{S}$ & $\mathrm{Si}$ & $\mathrm{Ni}$ & $\mathrm{Al}$ & $\mathrm{N}$ & $\mathrm{Mo}$ & $\mathrm{Nb}$ \\
\hline 26475 & 0.062 & 1.11 & 0.19 & 0.49 & 0.004 & 0.004 & 0.27 & 0.11 & 0.022 & 0.012 & 0.013 & 0.002 \\
\hline
\end{tabular}

TABLE 2. The complex of mechanical properties of 06Kh1 steel.

\begin{tabular}{|c|c|c|c|c|c|c|c|}
\hline \multirow{3}{*}{$\begin{array}{l}\text { Tube size, } \\
\text { mm }\end{array}$} & \multicolumn{7}{|c|}{ Mechanical properties } \\
\hline & \multirow{2}{*}{$\begin{array}{c}\sigma_{\mathrm{S}} \\
\mathrm{N} / \mathrm{mm}^{2}\end{array}$} & \multirow{2}{*}{$\begin{array}{c}\sigma_{\mathrm{S}}, \\
\mathrm{N} / \mathrm{mm}^{2}\end{array}$} & \multirow{2}{*}{$\sigma_{\mathrm{Y}} / \sigma_{\mathrm{S}}$} & \multirow{2}{*}{$\delta_{5}, \%$} & \multicolumn{3}{|c|}{$\mathrm{KCV}, \mathrm{J} / \mathrm{cm}^{2}$ at $T,{ }^{\circ} \mathrm{C}$} \\
\hline & & & & & -20 & -40 & -60 \\
\hline \multicolumn{2}{|c|}{$\varnothing 114 \times 9 \mathrm{~m} \mathrm{430-470}$} & $381-413$ & $0.67-0.70$ & $32-37$ & $381-413$ & $378-403$ & $356-396$ \\
\hline
\end{tabular}




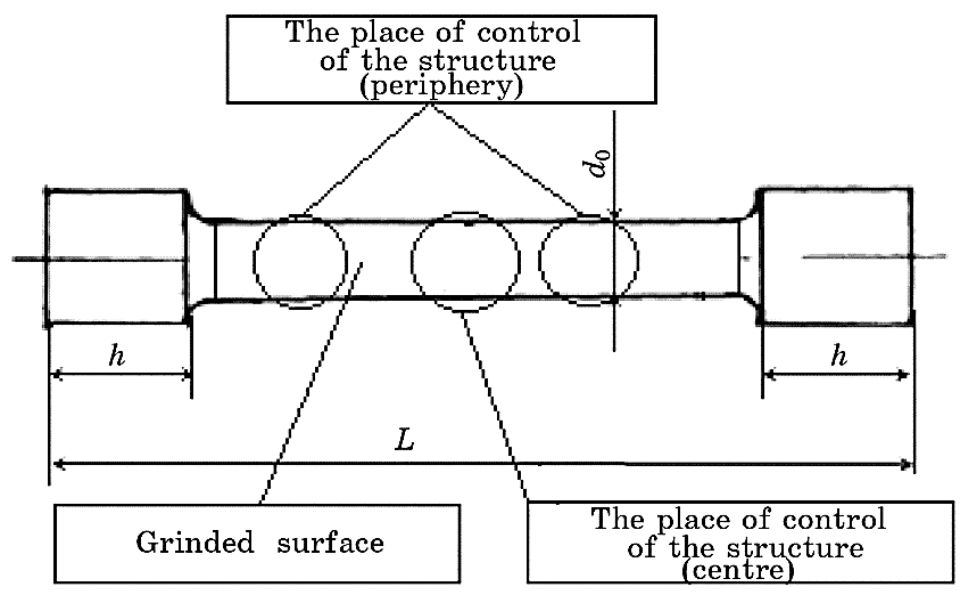

Fig. 1. The schematic image of the studied sample $\left(L=50 \mathrm{~mm}, d_{0}=5 \mathrm{~mm}, h=\right.$ $=10 \mathrm{~mm}$ ) with places of structure control on periphery and centre.

boundaries' types was made according to the methodology offered in the work [9].

\section{RESULTS AND DISCUSSION}

The investigation results of the places of fracture origination are given in Figs. 4-5.

The analysis of the data shows that strengthening as a result of plastic deformation prevents the development of fracture in the direction perpendicular to the active areas of slip, however, it promotes the growth of microcracks in the direction of the areas of slip at the edges of these areas situated near the boundaries of grains or fragile structural components (see for example Figs. 4, $b, c$, and 5, $b$ ).

Despite the fact that the local concentration of tensions in pearlite under the deformation of 'grain' in general can be higher than ferrite grain after a significant deformation, the static strength of pearlite grains is higher than the strength of ferrite grains. It is proved by the fact that pearlite structure (to a certain level of loading) withstands the spread of plastic deformation (see for example Fig. $5, d$ ).

The overall analysis of the investigation data given in this work and

TABLE 3. The efforts of samples' loading at testing for extension.

\begin{tabular}{c|ccccc}
\hline Number of sample & 1 & 2 & 3 & 4 & 5 \\
\cline { 1 - 3 } Effort of loading $P, \mathrm{~N}$ & 3033.8 & 3079.0 & 3806.3 & 3900.0 & 3981.0 \\
\hline
\end{tabular}




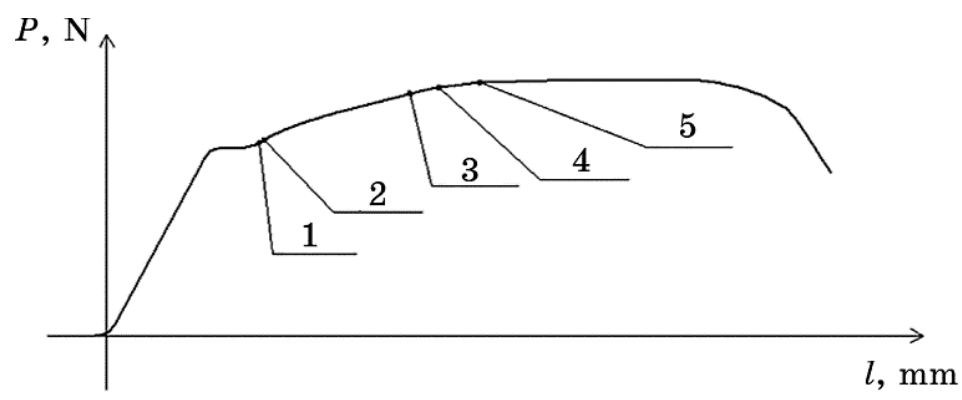

Fig. 2. The diagram of the experimental extension of the samples (Nos. 1-5) of $06 \mathrm{Kh} 1$ steel.

scientific sources (e.g., $[1,3,5,6])$ makes it possible to conclude that the origination of microcracks is not the only criterion of the resistance of steel fracture. The same importance is given to the factor of the conditions, which make it possible to unite the cracks after reaching their certain density until the material fracture. This process is influenced by not only the quantity and the direction of tensions in the area of fracture origination, but also structural state of the material, the surface type of division, and the strength of structural components.

For example, in Fig. 5, $b$, there is the situation when inner-phase boundary simultaneously prevents the process of microcracks coalescence and is the origin of transcrystalline fracture. Herewith, the growth of this microcrack more likely takes place according to Cottrell's mechanism [10], which is proved by the existence of slip stripes, which are included to microcracks.

Figure $5, d$ represents the case where the interphase boundary fer-
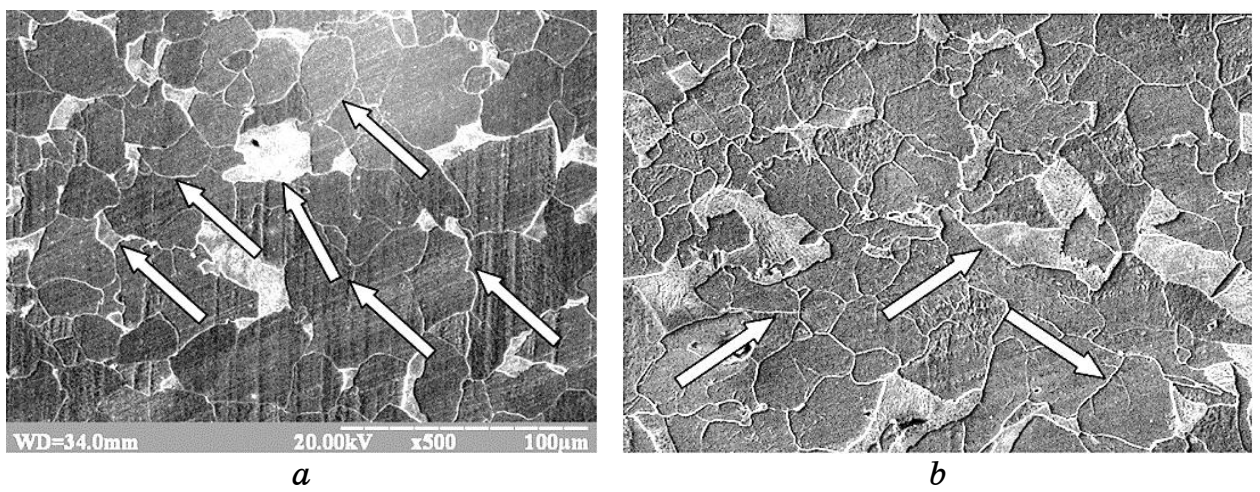

Fig. 3. The 06Kh1 steel structure before the beginning of deformation: $a$-the boundaries of general type (the example is indicated with the arrow); $b$-the boundary of special type (the example is indicated with the arrow). 

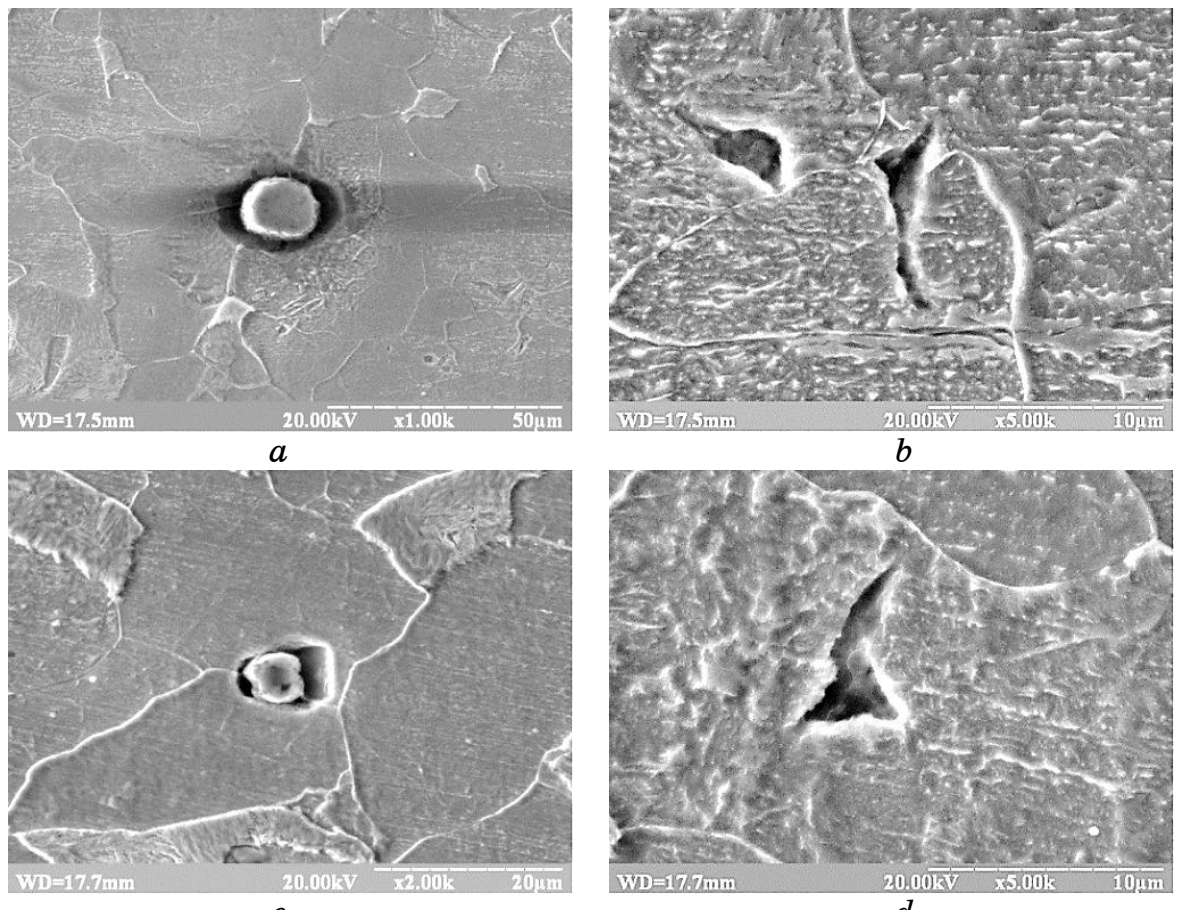

$d$
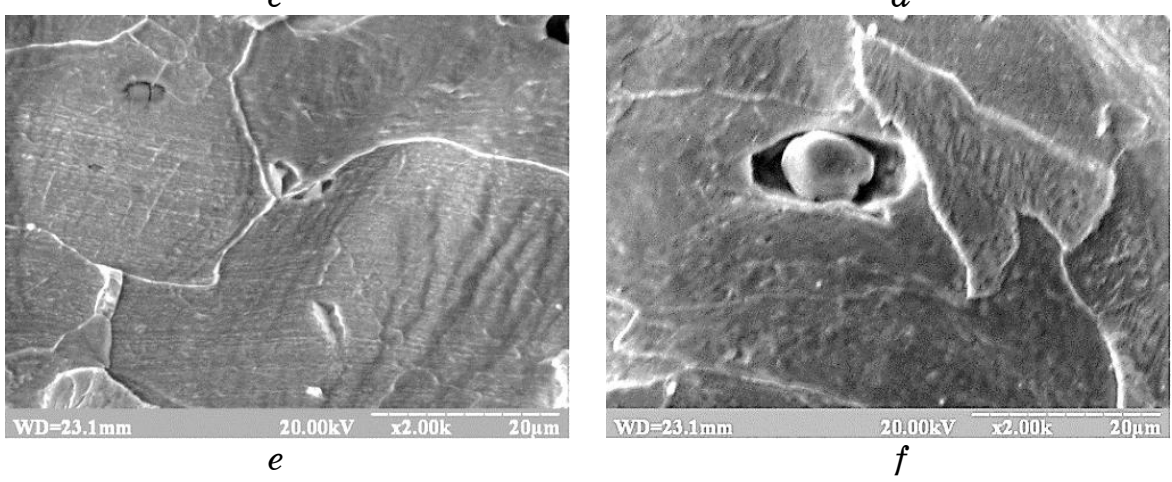

Fig. 4. The samples of structures after the extension with the loading: $a, b-$ $3033.8 \mathrm{~N} ; c, d-3079 \mathrm{~N} ; e, f-3806.3 \mathrm{~N} ; a, c, e$-centre, $b, d, f$-periphery.

rite-pearlite is a barrier for the spread of plastic deformation and the growth of microcracks.

At the same time, in the place of the ternary joint of the surfaces division (indicated with the arrow in the Fig. 5), the branching of cracks takes place, which is a characteristic feature of a fragile mechanism of fracture [11]. That is, in this case, unlike the situations in Fig. 5, $b$, there is a bit different mechanism of fracture spreading. It can be supposed that together with the growth of external loading, the crack 


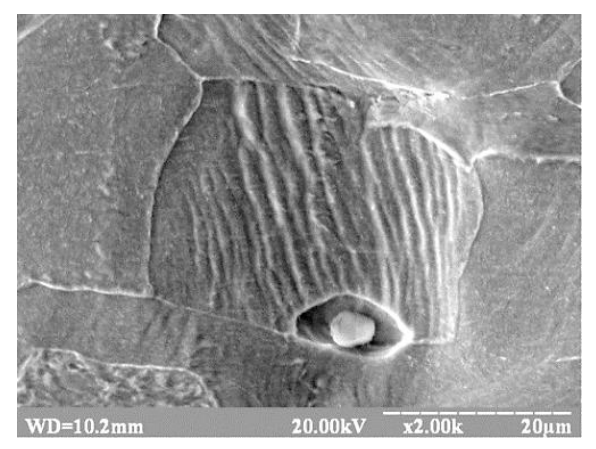

$a$

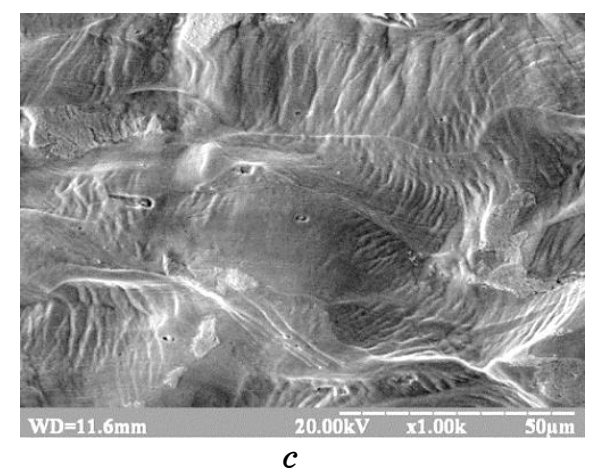

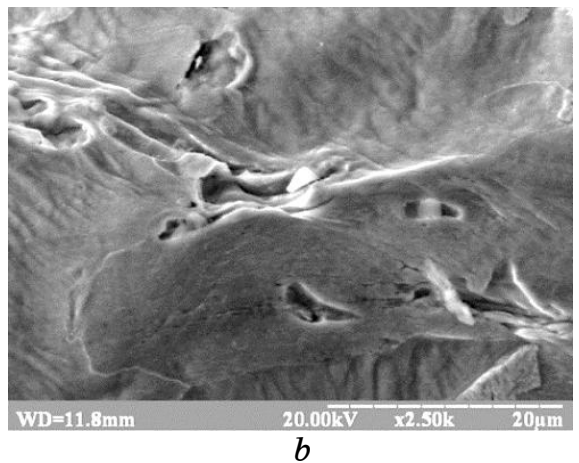

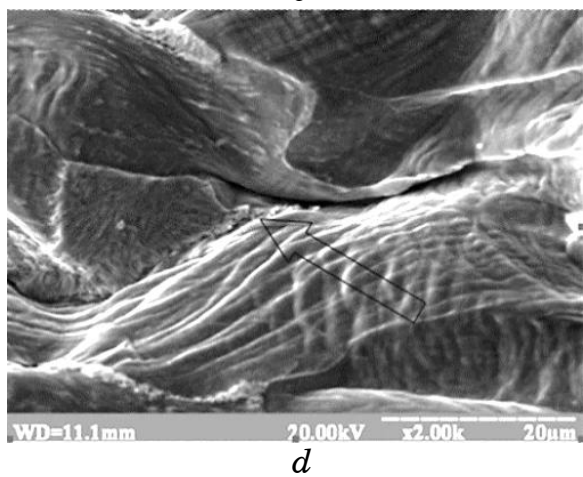

Fig. 5. The samples of structures after extension with the loading: $a, b-3900$ $\mathrm{N} ; c, d-3981 \mathrm{~N} ; a, c$-centre, $b, d$-periphery.

branching will continue. This will lead to the origination of microcracks on the boundary ferrite-pearlite, which will grow into a pearlite colony at the expense of the fracture of the separation surface ferrite-cementite.

Summarizing the investigation data, it is possible to define several probable places of fracture origination in low-carbon microalloyed

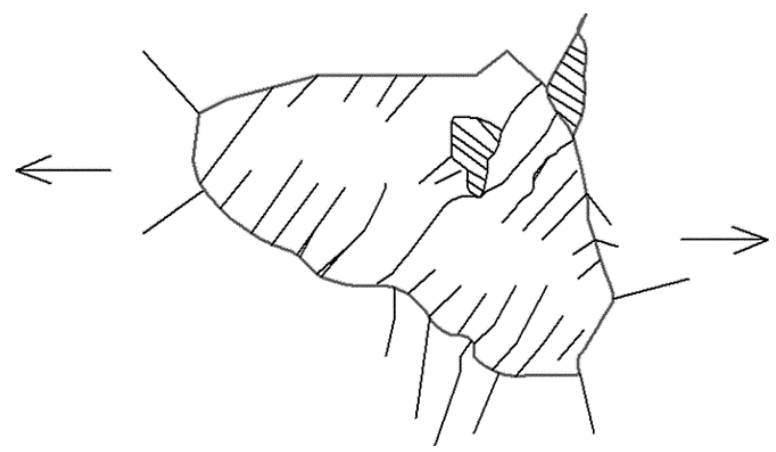

Fig. 6. The scheme of cracks origination in ferrite component of steel structure. 
steels. Schematically these places are given in Fig. 6 .

\section{CONCLUSIONS}

1. Under the even distribution of tension on the sample intersection, plastic deformation develops almost simultaneously in several ferrite grains. Herewith, the increase in external loading leads to the development of plastic deformation at the structural components.

2 . The investigations carried out showed that blocking of plastic deformation takes place on the separation surfaces, which have heightened level of free energy.

3 . For the ferrite component of low-carbon microalloyed steels, it was shown that deformation blocking takes place on the separation surfaces, a portion of the second phase is matrix and interphase and innerphase boundaries.

4. The results show that in low-carbon microalloyed steels the origination and development of ductile fracture can happen at the expense of simultaneous actions of two mechanisms: the origination and coalescence of microcavities and by the way of blocking the active areas of slip by the ferrite-ferrite and ferrite-pearlite boundaries. Herewith, the growth of microcracks to the critical size happens at the expense of both accumulation of dislocations (Cottrell's model) and aggregation of several microcracks into single one.

\section{REFERENCES}

1. Kh. A. Rakhmatullin, E. I. Shemyakin, Yu. A. Dem'yanov, and A. V. Zvyagin, Prochnost' $i$ Razrushenie pri Kratkovremennykh Nagruzkakh [Strength and Fracture under Short-Term Loads] (Moscow: Universitetskaya Kniga 'Logos': 2008) (in Russian).

2. O. V. Beketov, S. V. Ivantsov, I. A. Tyuterev, N. O. Rott, and E. O. Babenko, Stroitel'stvo, Materialovedenie, Mashinostroenie, Iss. 95: 26 (2017) (in Ukrainian).

3. G. F. Sarafanov and V. N. Perevezentsev, Zakonomernosti Deformatsionnogo Izmel'cheniya Struktury Metallov i Splavov [Regularities of Deformation Grinding of the Structure of Metals and Alloys] (Nizhniy Novgorod: 2007) (in Russian).

4. A. N. Orlov, V. N. Perevezentsev, and V. V. Rybin, Granitsy Zeren v Metallakh [Boundaries of Grains in Metals] (Moscow: Metallurgiya: 1980) (in Russian).

5. A. Nadai, Plastichnost i Razrushenie Tverdykh Tel [Plasticity and Destruction of Solids] (Moscow: Izd. Inostrannoy Literatury: 1954) (in Russian).

6. J. F. Nott, Osnovy Mekhaniki Razrusheniya [Fundamentals of Fracture Mechanics] (Moscow: Metallurgiya: 1978) (Russian translation).

7. Kh. Vashul', Prakticheskaya Metallografiya. Metody Izgotovleniya Obraztsov [Practical Metallography. Methods for Samples Fabrication] (Moscow: Metallurgiya: 1988) (in Russian). 
8. J. Goldstein, Prakticheskaya Rastrovaya Elektronnaya Mikroskopiya [Practical Scanning Electron Microscopy] (Moscow: Mir: 1978) (Russian translation).

9. V. I. Bol'shakov, G. D. Sukhomlin, and D. V. Laukhin, Atlas Metallov i Splavov: Uchebnoe Posobie [Atlas of Metals and Alloys: Tutorial] (Dnipro: GVUZ 'Pridneprovskaya Gosudarstvennaya Akademiya Stroitel'stva i Arkhitektury': 2010) (in Russian).

10. V. M. Finkel', Fizika Razrusheniya [Fracture Physics] (Moscow: Metallurgiya: 1970) (in Russian).

11. V. Z. Parton and V. G. Barkovskiy, Dinamika Khrupkogo Razrusheniya [Dynamics of Brittle Fracture] (Moscow: Mashinostroenie: 1988) (in Russian). 